\title{
Perancangan Mesin Cuci Tangan Otomatis dan Higienis Berbasis Kamera
}

\author{
Hanifudin Sukri \\ Teknik Elektro Universitas Trunojoyo Madura \\ hanifudinsukri@trunojoyo.ac.id
}

DOI: https://doi.org/10.21107/rekayasa.v12i2.5540

\begin{abstract}
ABSTRAK
Mencegah penyebaran infeksi dan kuman pada saat kegiatan makan, mencuci tangan merupakan hal yang paling direkomendasikan. Untuk meningkatkan kesadaran masyarakat, Pemerintah telah mencanangkan dan memberikan panduan dan tatacara yang benar dalam proses cuci tangan. Pada penelitian ini untuk mempermudah kegiatan cuci tangan dan menghemat air, dibuat sebuah mesin pencuci tangan otomatis. Alat ini dirancang menitik beratkan pada kebersihan dan kehigienisan tangan pada saat mencuci tangan. Mesin ini terdiri dari 3 bagian yaitu kran air otomatis, kran sabun otomatis, dan pengering otomatis. Kran air otomatis terbuka saat mendeteksi adanya tangan menggunakan sensor ultrasonik dan kamera dengan deteksi bentuk tangan dan jarak tangan $20<\operatorname{tangan}<30 \mathrm{~cm}$. Selanjutnya kran sabun akan terbuka otomatis jika mendeteksi jarak tangan $10<$ tangan $<15 \mathrm{~cm}$ dan pengering otomatis jika mengidentifikasi jarak tangan kurang dari $5 \mathrm{~cm}$. Bentuk tangan dideteksi melalui kamera menggunakan Haar-Training dengan 50 posiitif dan 30 negatif image yang diterjemahkan dalam bentuk XML.
\end{abstract}

Kata-kunci: kran air otomatis, kran sabun otomatis, pengering otomatis, haar-Training

\section{ABSTRACT}

\section{Design of a Camera-Based Automatic and Hygienic Hand Washing Machine}

To prevent the spread of infection and germs when eating, hand washing is the most recommended. To increase public awareness, the Government has launched and provided guidelines and correct procedures for hand washing. In this study to facilitate hand washing and water saving activities, an automatic hand washing machine was made. This tool is designed to focus on cleanliness and hygiene of hands when washing hands. This machine consists of 3 parts, namely automatic water faucets, automatic soap faucets, and automatic dryers. The water faucet automatically opens when it detects a hand using an ultrasonic sensor and a camera with hand shape detection and a hand distance of $20<$ hand $<30 \mathrm{~cm}$. Furthermore, the soap faucet will open automatically if it detects $10<$ hand $<15 \mathrm{~cm}$ hand distance and automatic dryer if it identifies less than $5 \mathrm{~cm}$ hand distance. The shape of the hand is detected through the camera using Haar-Training with 50 positives and 30 negative images translated in XML.

Keywords: automatic water faucet, automatic soap faucet, automatic dryer, haar-Training

\section{PENDAHULUAN}

Mencuci tangan merupakan hal yang paling penting, sederjana dan paling efektif dalam proses memelihara kesehatan yang ditimbulkan oleh penyakit menular (A. E. Aiello, dkk 2008). Mencuci tangan harus menggunakan air bersih dan bebas kuman. Rata-rata durasi cuci tangan yang di rekomendasikan WHO adalah 20 hingga 30 detik (D. Pittlet, 2009). Cuci tangan menggunakan sabun dan air bersih lebih efektif untuk menghilangkan bakteri dari pada mencuci dengan air saja hingga 23\% (M. Burton, 2011). Penelitian lain menunjukkan bahwa kepatuhan mencuci tangan sesuai standar yang dikeluarkan dinas kesehatan, meningkatkan kebersihan sekitar 40\%, bahkan jika setelah seseorang mengikuti berbagai pelatihan dalam hal mencuci tangan, akan menaikkan prosentasi menghilangkan bakteri sebesar 50\%. Penelitian

\section{Article History:}

Received: July, 12 $2019 ;$ Accepted: September, $29^{\text {th }} 2019$ ISSN: 2502-5325 (Online) Terakreditasi Peringkat 3 oleh Kementerian Riset, Teknologi dan Pendidikan Tinggi (ARJUNA), berdasarkan Keputusan Direktur Jenderal Penguatan Riset dan Pengembangan No: 23/E/KPT/2019 tanggal 8 Agustus 2019 lain juga mengemukakan bahwa mencuci tangan dengan menggunakan sabun akan menghilangkan bakteri dan kuman-kuman pembawa penyakit hanya dengan durasi 15 detik (J. M. Boyce dan D. Pittet, 2002).

Disebuah super market, Plaza, atau tempat makan, sudah menggunakan mesin cuci tangan otomatis. Para pengguna cukup menengadahkan tangan dan air otomatis keluar. Dalam mesin tersebut digunakan sensor proximity yang menggunakan cahaya infrared untuk mendeteksi adanya tangan atau benda lain (Fitriyah H, dkk 2018). Tapi sayangnya alat tersebut tidak dapat mendeteksi tangan dengan sempurna, hanya mendeteksi objek secara universal. Artinya jika pada kran ditempelkan benda apapun, maka air pasti akan keluar secara otomatis walaupun bukan tangan yang dideteksi. Perancangan mesin cuci tangan otomatis sudah

\section{Cite this as:}

Sukri, H. (2019). Perancangan Mesin Cuci Tangan Otomatis dan Higienis Berbasis Kamera. Rekayasa, 12(2), 163-167. doi:https:// doi.org/10.21107/rekayasa.v12i2.5540

(C) 2019 Hanifudin Sukri 
dilakukan sejak tahung 1999, didalamnya terdiri dari kran air otomatis, sabun otomatis, dan pengering otomatis. Pada penelitian tersebut, mesin dirancang menggunakan komponen pipa mekanis (E. Stanley dan Sr. Flowers, 1999). Penelitian lain mesin pencuci tangan otomatis dikembangkan menggunakan kontrol elektronik berbasis timer (A. Bianchi, D. M, 2009). Dalam beberapa tahun terakhir penelitian tentang mesin cuci tangan otomats sudah berkembang menggunakan sensor kamera (Fernández Llorca, dkk 2011) sebagai sensor untuk mendeteksi keberadaan dan posisi tangan (Xia Baiqiang, dkk 2015).

Melihat beberapa penelitian yang sudah dilakukan, belum ada penelitian yang berusaha untuk membuat kalibrasi image tangan yang dikombinasikan dengan sensor lain agar air atau sabun yang keluar sesuai dengan yang diinginkan. Dalam penelitian ini dirancang sebuah mesin cuci tangan otomatis dengan kombinasi sensor kamera dan sensor ultrasonik. Proses pendeteksian tangan menggunakan Haar-Training Algorithm untuk menentukan objek dibawah kran air dan sabun adalah benar-benar tangan. Kombinasi deteksi tangan menggunakan kamera dan jarak tangan dengan kran menggunakan sensor ultrasonik merupakan solusi akurat dan efektif untuk memastikan bahwa air dan sabun bisa keluar dari kran ketika hanya mendekesi tangan (bukan objek lain) dengan jarak yang sudah ditentukan.

\section{METODE PENELITIAN}

\section{A. Diagram Blok}

Secara keseluruhan, alur sistem dapat dilihat pada Gambar 1. Terdapat dua sensor yakni sensor kamera dan sensor ultrasonik, mikrokontroller sebagai pemroses atau sistem kontrol utama serta tiga actuator berupa solenoid valve untuk kran air dan sabun serta hand dryer. Kedua sensor ini berfungsi untuk memberikan masukan kepada mikrokontroller. Masukan yang diberikan berupa bentuk tangan yang dihasilkan oleh kamera serta jarak tangan terhadap mesin. Mikrokontroller berfungsi untuk memproses dan menganalisis apakah objek yang dideteksi merupakan bentuk tangan atau bukan. Selanjutnya objek tersebut akan diukur jika jarak objek dengan mesin diantara $20<$ tangan < $30 \mathrm{~cm}$ maka kran air yang terbuka, jika jarak objek dengan mesin diantara $10<$ tangan < $15 \mathrm{~cm}$, maka kran sabun yang terbuka, dan jika jarak objek dengan mesin kurang dari $5 \mathrm{~cm}$ maka hand dryer aktif.

B. Klasifikasi Bentuk Tangan Menggunakan Haar-Training

Deteksi bentuk tangan digunakan sebagai parameter utama untuk membuka kran air. Ini dilakukan agar jika kamera mendeteksi selain objek bentuk tangan maka kran tidak akan terbuka. Tahapan pendeteksian dan klasifikasi bentuk tangan menggunakan algoritma Haar-Training seperti pada Gambar 2 (Paul Viola and Michael J. Jones, 2001).

Langkah awal yakni proses capture, proses ini menangkap semua objek oleh kamera dan ditampilkan dalam sebuah frame. Bagian image yang dicurigai tangan akan di crop dan dilanjutkan dengan proses konversi kedalam bentu grey image, saturasi dan threshold. Image yang diihasilkan pada proses sebelumnya akan diidentifikasi untuk mendapatkan informasi image yang akan

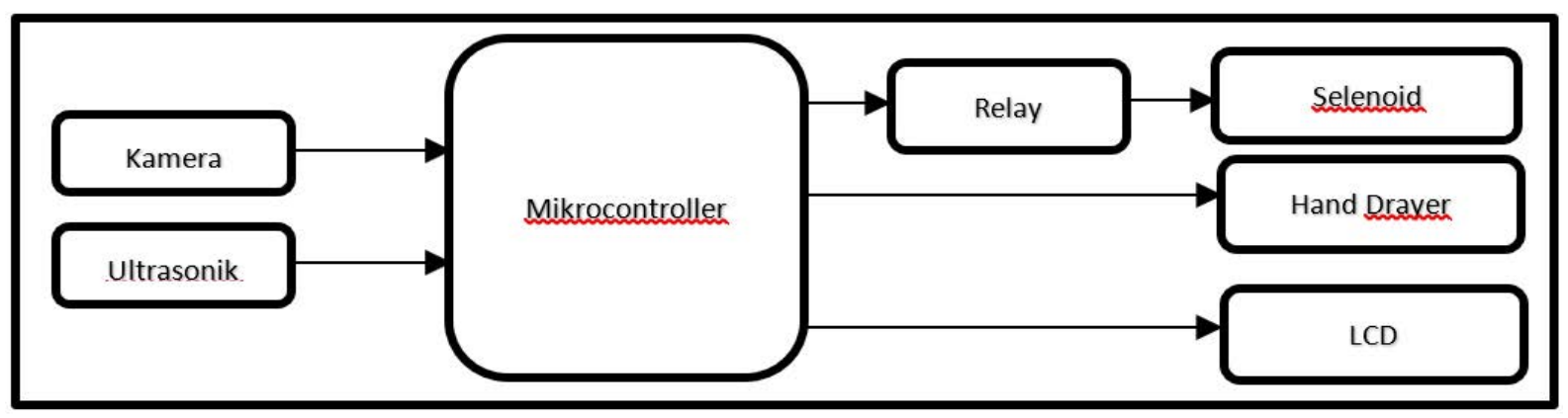

Gambar 1. Blok Diagram Sistem

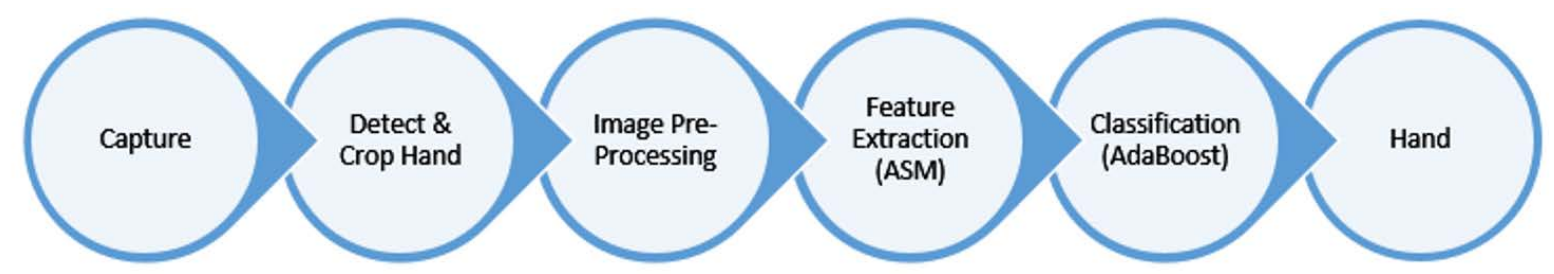

Gambar 2. Metodologi Pendeteksian Bentuk Tangan 
digunakan pada proses klasifikasi. Informasi yang dihimpun antara lain memecah data gambar perkarakter, normalisasi ukuran piksel serta konfersi data piksel kedalam bentuk binary. Selanjutnya image akan ditraining menggunakan algoritma AdaBoost.

\section{HASIL DAN PEMBAHASAN}

Langkah awal yang dilakukan dalam penelitian ini adalah pendeteksian bentuk tangan. Bentuk tangan harus dideteksi untuk memastikan bahwa objek yang berada dalam area kerja adalah benar-benar tangan agar jika kamera mendeteksi selain bentuk tangan maka kran air tidak akan terbuka. Hal ini sangat penting dilakukan, mengingat fungsi dari mesin yang dibuat adalah mesin cuci tangan otomatis. Jika hanya menggunakan sensor ultrasonik saja, maka jika terdapat objek lain selain tangan kran air terbuka, artinya jika ada benda atau objek lain bisa saja kran akan terbuka dan air terbuang percuma. Dalam proses ini bentuk tangan yang akan diidentifikasi menggunakan sensor kamera menggunakan algoritma Haar-Training. Sebelumnya peneliti menyiapkan beberapa sampel bentuk tangan seperti pada Gambar 3 yang akan dijadikan dasar pengambilan keputusan disimpan dalam sebuah database dan dikonversi menjadi bentuk XML. Berikut ini sampel image bentuk tangan yang akan di identifikasi dan diklasifikasi.

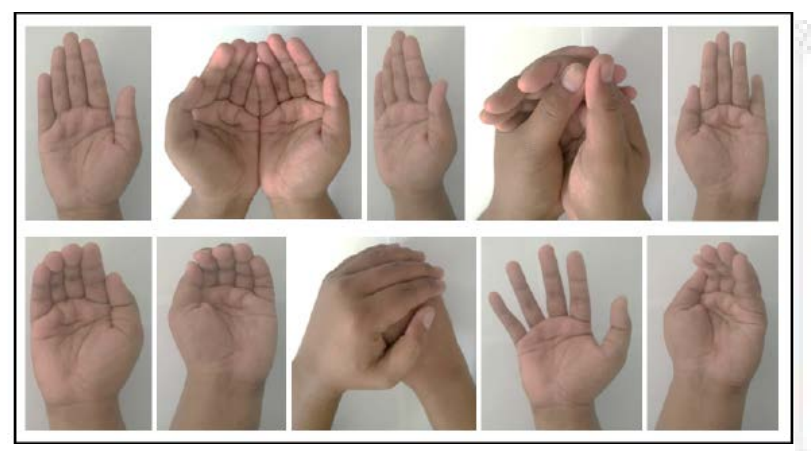

Dari beberapa sample positif tersebut kemudian dikonversi menjadi image negatif dan selanjutnya diproses perubahan ukuran sesuai area kerja. Setelah seluruh data positif dan negatif terkumpul, kemudian diambil titik koordinat yang akan digunakan untuk pengaturan posisi tampilan objek bentuk tangan. Data koordinat image yang sudah dikumpulkan akan disimpan dalam sebuah file yang akan dilatih hingga menjadi bentuk cascade. Selanjutnya dilakukan proses pelatihan data, sample image diproses dalam bentuk ukuran piksel $A^{*} B$, dimana piksel $A$ merupakan lebar image dan piksel $B$ merupakan tinggi image dan hasil pelatihan dikonversi dalam bentuk XML. Dalam hal ini ukuran piksel yang diterapkan yaitu $600 \times 600$ piksel.

Hasil deteksi bentuk tangan ditunjukkan pada Gambar 4 yang diringkas pada Tabel 1. Dari 10 kali percobaan, sistem dapat mengenali bentuk tangan $100 \%$ tanpa mengalami kesalahan. Bentuk tangan yang dideteksi ditandai dengan kotak merah oleh sistem. Hal ini menunjukkan bahwa algoritma Haar-Training dapat diandalkan dalam sistem pendeteksian objek. Ini juga membuktikan bahwa banyaknya jumlah sample image sangat mempengaruhi hasil pendeteksian.

Langkah selanjutnya sistem pendeteksian diintegrasikan dengan pendeteksian jarak objek menggunakan sensor ultrasonik untuk memastikan kran
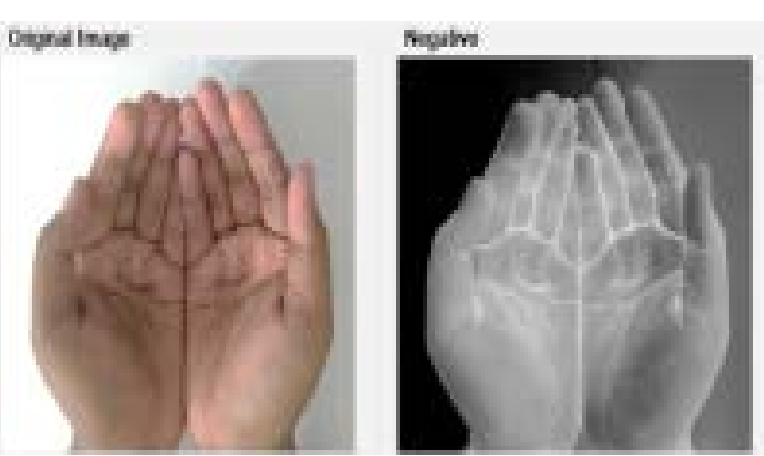

Gambar 3. (a) Positif Image Sample, (b) hasil konversi positif image ke bentuk negative

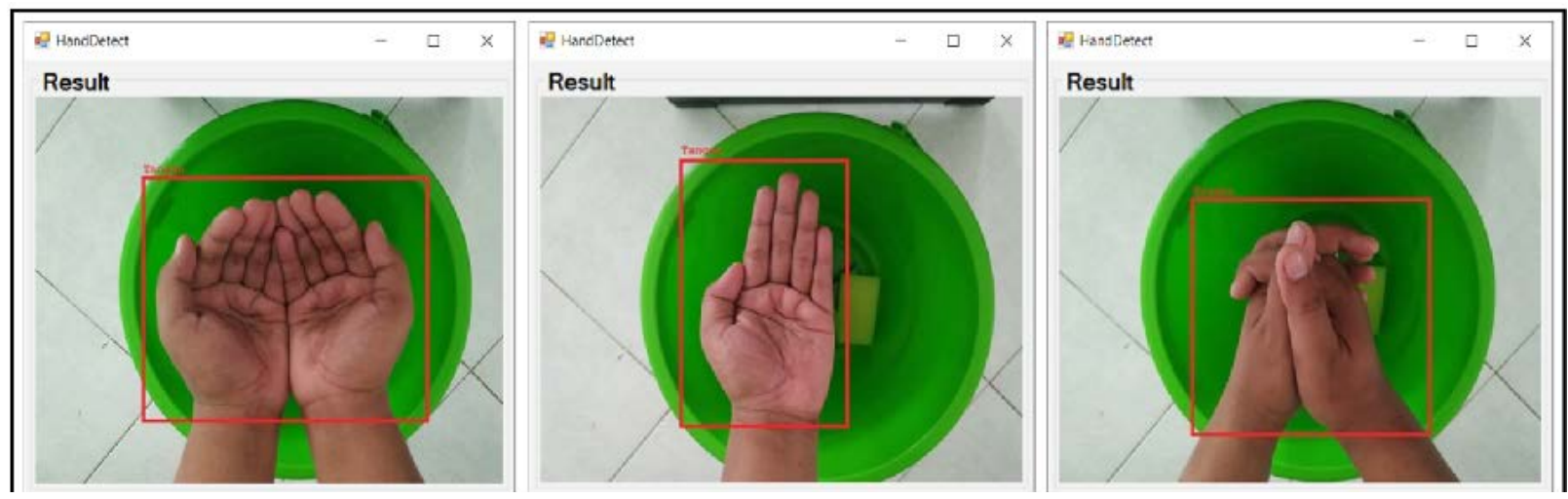

Gambar 4. Hasil Deteksi Bentuk Tangan 
Tabel 1. Hasil Pendeteksian Bentuk tangan

\begin{tabular}{ccc}
\hline Sample & Berhasil & Gagal \\
\hline 1 & 1 & 0 \\
2 & 1 & 0 \\
3 & 1 & 0 \\
4 & 1 & 0 \\
5 & 1 & 0 \\
6 & 1 & 0 \\
7 & 1 & 0 \\
8 & 1 & 0 \\
9 & 1 & 0 \\
10 & 1 & 0 \\
\hline
\end{tabular}

Tabel 2. Hasil Pengujian Jarak Objek dengan Sensor Utrasonik

\begin{tabular}{ccc}
\hline Percobaan & $\begin{array}{c}\text { Jarak Riil } \\
\text { (cm) }\end{array}$ & $\begin{array}{c}\text { Jarak Pengukuran } \\
\text { (cm) }\end{array}$ \\
\hline 1 & 2 & 2 \\
2 & 4 & 4 \\
3 & 5 & 5 \\
4 & 11 & 10 \\
5 & 13 & 13,2 \\
6 & 15 & 14,8 \\
7 & 22 & 22,4 \\
8 & 25 & 26 \\
9 & 28 & 27,8 \\
10 & 30 & 31 \\
\hline
\end{tabular}

air dapat terbuka. Sensor ultrasonik yang digunakan yang bersifat waterproof yakni tipe JSN-04T. Dalam Table 2 disajikan hasil pengukuran jarak objek dengan sensor ultrasonik.

Berdasarkan beberapa kali percobaan, sistem secara keseluruhan dapat bekerja dengan baik. Kran air dapat terbuka setelah mendeteksi bentuk tangan dan mengidentifikasi jarak tangan dalam rentang 20 sampai $30 \mathrm{~cm}$. Begitu juga dengan kran sabun langsung terbuka otomatis ketika mendeteksi objek dengan jarak 10 sampai $15 \mathrm{~cm}$. sedangkan hand dryer juga berfungsi dengan baik, yakni otomatis mengeluarkan udara panas pada saat mendeteksi objek kurang dari $5 \mathrm{~cm}$. Dalam Tabel 2 disajikan 6 kali percobaan sistem secara keseluruhan. Dan dari ke 6 percobaan tersebut sistem berhasil melaksanakan tugasnya dengan baik tanpa sekalipun melakukan kesalahan.

\section{KESIMPULAN DAN SARAN}

Sistem kecara keseluruhan bekerja dengan sangat baik. Tentunya hal ini didukung dengan proses pendeteksian bentuk tangan yang selalu berhasil mendeteksi bentuk tangan dengan akurat serta deteksi jarak objek berjalan sangat cepat dan presisi dengan error yang sangat minimal. Untuk memastikan keberhasilan pendeteksian bentuk tangan, maka jumlah sample image harus seimbang antara positive image dengan negative image dengan ukuran sample 600x600 piksel. Begitu juga dengan sensor ultrasonik yang digunakan harus bersifat waterproof agar tidak terjadi masalah.

\section{DAFTAR PUSTAKA}

A. Bianchi, D. M, (2009). WHO Guidelines on Hand Hygiene in Helath Care: a Summary. World Health Organization Patient Safety: University of Geneva Hospitals

A. E. Aiello, R. B. Coulborn, V. Perez, and E. L. Larson, (2008). Effect on Hand Hygiene on Infectious Disease Risk in the Community Setting: A-MetaAnalysis, in American Journal of Public Health, 98(8), 1372-1381

D. Pittlet, (2009). WHO Guidelines on Hand Hygiene in Helath Care: a Summary. World Health Organization Patient Safety: University of Geneva Hospitals

E. Stanley and Sr. Flowers, (1999). Automatic Hand Washing and Drying Machine, U.S. Patent US5924148A

Fernández Llorca D., Parra Ignacio, Ángel Sotelo M., Lacey Gerard, (2011). A vision-based system for automatic hand washing, Machine Vision and Applications

Fitriyah H., Rosana Widasari E., Setiawan Eko, Angga Kusuma B., Interaction design of automatic faucet for standard hand-wash, MATEC Web of Conferences 154, 03003 (2018)

Tabel 2. Percobaan Sistem Secara Keseluruhan

\begin{tabular}{ccccccc}
\hline Percobaan & Deteksi tangan Deteksi Jarak & Kran Air & Kran Sabun & Hand Dryer & Keterangan \\
$(\mathrm{cm})$ & 23 & Terbuka & Tertutup & Tertutup & Berhasil \\
1 & 1 & 26,2 & Terbuka & Tertutup & Tertutup & Berhasil \\
2 & 1 & 11,4 & Tertutup & Terbuka & Tertutup & Berhasil \\
3 & 0 & 14 & Tertutup & Terbuka & Tertutup & Berhasil \\
4 & 0 & 3 & Tertutup & Tertutup & Terbuka & Berhasil \\
5 & 0 & 3.7 & Tertutup & Tertutup & Terbuka & Berhasil \\
6 & 0 & & & & &
\end{tabular}


J. M. Boyce and D. Pittet, (2002). Guideline for Hand Hygiene in Health-Care Settings: Recommendations of the Healthcare Infection Control Practies Advisory Comitte and the HICPAC/SHEA/ APIC/IDSA Hand Hygiene Task Force. Department of Health and Human Services: Morbidity and Mortality Weekly Report, USA

M. Burton, E. Cobb, P. Donachie, G. Judah, V. Curtis and W. P. Schmidt, (2011). The Effect of Handwashing with Water or Soap on Bacterial Contamination of hands, In International Journal of Environmental Research and Public Health, 8(1), 97-104

Mayo Clinic Staff, (2014). Hand-washing: Do's and Don'ts. Healthy Lifestyle Adulth Health
Paul Viola and Michael J. Jones. (2001). Rapid Object Detection using a Boosted Cascade of Simple Features. IEEE CVPR,

Rainer Lienhart and Jochen Maydt. (2002). An Extended Set of Haar-like Features for Rapid Object Detection. IEEE ICIP

V. Boscart, K. McGilton, A. Levchenko, G. Hufton, P. Holliday, and G. Fernie, (2008). Acceptability of a wearable hand hygiene device with monitoring capabilities, Journal of Hospital Infection, 70, 216222

Xia Baiqiang and friends, (2015). Hand Hygiene Poses Recognition with RGB-D Videos, Proceedings of the 17th Irish Machine Vision and Image Processing conference, IMVIP 